\title{
Reading on Paper and Scrolling Text on a Screen in Academic Learning
}

\author{
Ana Isabel Santos ${ }^{1}$ \\ Carlos Miguel Ferreira ${ }^{2}$ \\ Maria José Sá ${ }^{3 *}$ \\ Sandro Serpa ${ }^{4}$

\begin{abstract}
${ }^{1}$ University of The Azores, Faculty of Social Sciences and Humanities Interdisciplinary Centre for Childhood and Adolescence-NICA -Uac, The Azores, Portugal ${ }^{2}$ Interdisciplinary Centre of Social Sciences - CICS.NOVA, Portugal ISCTE - University Institute of Lisbon ${ }^{3}$ CIPES-Centre for Research in Higher Education Policies, Matosinhos, Portugal ${ }^{4}$ University of The Azores, Faculty of Social and Human Sciences, Department of Sociology Interdisciplinary Centre of Social Sciences - CICS.UAc/CICS.NOVA.UAC Interdisciplinary Centre for Childhood and Adolescence - NICA - UAc, The Azores, Portugal ${ }^{*}$ Corresponding Author
\end{abstract}

Doi: 10.36941/ajis-2019-0012

\begin{abstract}
In the contemporary context, there is a growing practice of reading higher education teaching support material using digital media tools, via scrolling text on a screen on multiple devices (e.g. tablets, iPads and computers). These materials can be either specifically prepared digital texts or scanned printed texts, as opposed to the tradition of reading on paper. Thus, the following question emerges, which functions as the leitmotiv of the present study: what is the pedagogical potential of digital reading by scrolling text? In order to answer this question, we analysed a variety of information addressing this topic, which was collected from multiple sources. The analysis of this information allows concluding that, sometimes, rather than by the intentionality or pedagogical potential of the academic learning reading processes, this practice seems to be justified by the possibility of implementing a technology that tends to meet the actors' expectations (mainly students). There is the need for some caution in the mobilisation of digital reading in each specific situation, insofar as this reading is not always necessarily and under any circumstance - the most fruitful. Besides the specificities that differentiate digital reading from printed reading (such as concentration and the relationship with new technologies), students' traits, their motivation, their knowledge about the use of the reading device or the type of digital document are some of the key elements to take into account for the success of learning through this reading process in academic learning, which, in addition, cannot overlook the importance of the type of teacher-student relationship established.
\end{abstract}

Keywords: Scrolling text on a screen, screen reading, printed reading, academic training, higher education

"Standing up, shuffling the text in a horizontal direction, or indoors, flipping through a heavy codex; outdoors or in an office, absorbed by the portable book, or sitting down, with the legs curled up under a keyboard and eyes glazed in the monitor light. All these gestures, although they became possible over time, were not necessarily excluded. What is meant, therefore, is that, cumulatively, the present reader knows more practices of reading than a reader from centuries ago".

(Ribeiro, 2009, p. 76) 


\section{Introduction}

We live in a society where reading is critical (Cassany \& Morales, 2008) and increasingly technological. In this society, reading - also of an academic nature - in a digital context is becoming widespread (Santos \& Serpa, 2017; Myrberg \& Wiberg, 2015; Long \& Szabo, 2016; Knight, 2015; Cline, 2012; Martin-Beltrán, Tigert, Peercy, \& Silverman, 2017; Golan, Barzillai, \& Katzir, 2018), in a true culture of the screen (Levratto, 2017). Even if there are some medical issues related to the use of this practice, such as vision problems or discomfort (Phamonvaechavan \& Nitiapinyasagul, 2017; Gudinavičius, 2016), they seem to be progressively overcome.

The texts produced intentionally to be read in digital environments, often in an online context, have specific features that, if technically well-designed, can benefit from the enormous potential of the digital world. In a look at some of the features of reading a text that takes the most of technical potential in the Internet milieu,

[...] the Internet text is in an open network environment and its main features are multi-textuality, non-linearity, multimedia format, diversity of sources and opportunity for interaction, and each of them imposes demands on the reader which are important to understand, in order to use it as an educational resource (Ruiz, Macías, \& Cano, 2017, p. 134).

However, despite these and other potentials and resources that the digital milieu can offer, the success of the digital reading process, even in the academic context, is not guaranteed. In fact, it is a mistake to assume that students master previous knowledge, both in terms of content and in terms of how to search, select and even look in a document. For example, students often experience difficulties in areas such as assessing the credibility of the sources used, the knowledge of scientific validity criteria, and they often reveal the tendency to look in secondary sources, regardless of their credibility, among other issues (Santos \& Serpa, 2017; Sá \& Serpa, 2018; Gil, 2016; Long \& Szabo, 2016; Tanjung, Ridwan, \& Gultom, 2017).

In summary, regardless of the type and form of digital reading, for it to be productive, it is vital for those who use this means to have previous knowledge about the topic of the text, as well as competencies in the use of the Internet or the specific means of reading (Ruiz et al., 2017).

These difficulties in selecting digital reading reveal that the ability to browse the Internet is not necessarily the same as the ability to perform a successful reading, although the current generation of higher education students is often regarded as the digital generation, with strong skills in this field. This is, in fact, another reason to foster digital literacy in higher education (Santos \& Serpa, 2017), as well as the importance of recommending texts that are central for the study.

Perhaps even for the aforementioned reasons, added to the myriad of information that can be mobilised in the digital and the online world, textbooks and other teaching materials seem to continue to be generally viewed in the academic context as critical, and are often regarded as "reliable tools which provide creditable information that supports and enhances students' understanding of critical concepts, and that they present bite-size chunks of information to cement student learning" (Knight, 2015, p. 1).

This paper focuses on digital reading carried out on a technological screen in the context of academic learning through scrolling text on a screen, encompassing different types of written documents, such as originally printed texts which are directly transposed through their scanning (Gil, 2016; Gulley, 2013) or texts purposely produced for the online environment, such as e-books and e-journal articles.

This teaching material may, thus, take on the printed and/or the digital format (scanned texts or texts specifically prepared for that purpose), and there is the tendency towards reducing both the use and the expectation of use of printed texts (Lincoln, 2013; Knight, 2015; Tanjung et al., 2017; Myrberg \& Wiberg, 2015; Singer \& Alexander, 2017; Sackstein, Spark, \& Jenkins, 2015; Lenard, Schroeders, \& Lenhard, 2017).

Considering the context described above, this paper intends to reflect on these situations that take place with increasing frequency, in which the student has to carry out a screen reading of a text suggested by the teacher. Thus, the paper seeks to answer the following research question: 
does screen-scrolling text reading of textbooks and teaching materials have advantages in students' learning, vis-a-vis their reading on a printed version?

The paper is structured as follows: next section briefly puts forth the state-of-the-art on the topic of the reading of academic texts in the study at the higher education level. Section 3 describes the methodology used in this piece of research. Subsequently, the most relevant issues associated with reading in a scrolling text screen are presented and discussed. The paper concludes with some final remarks.

\section{The Reading of Academic Writing in the Study at the Higher Education Level}

Reading and writing are acknowledged as key elements for the learning process in the academic context (Upegui, Ceballos, Rendón, \& Gil, 2013; Cassany \& Morales, 2008). However, reading is neither an accessible nor an easy process. Shihab (2011) argues that

Reading is a sophisticated activity, which includes psychological, linguistic, and sociological aspects. It is an interactive process between a reader and [the] text. The process of reading involves constructing meaning among the parts of the text and between the text and readers' personal experience. The reader takes the text and gives it meaning (p. 209).

In turn, Cassany and Morales (2008) maintain that, according to the social-cultural perspective, the tasks of reading and writing are cultural and are deeply rooted in the social context where they take place, and which makes them vary throughout space and time. The authors state that

Each language or cultural community, each knowledge discipline, develops particular literate practices, with distinctive features. Apart from the fact that there may be general cognitive skills, utilised by all users in any context, reading and writing also involve learning the cultural conventions of each environment (p. 71).

Also according to Cassany and Morales (2008), the expression academic writing is used when referring to the body of scientific publications produced in the diverse areas of knowledge. However, while all of them share some common features, such as high specificity, objectivity and accuracy, each scientific discipline has cultural, social-cognitive, discursive and linguistic particularities that must be weighed to better understand the different ways of the reading and writing of each distinct professional and scientific practice.

Digital reading undeniably entails specificities in comparison with printed reading (Gil, 2016), regardless of the type of texts, including textbooks and other teaching material (Knight, 2015). Carioli (2014) points out that the reading of a text in a digital environment and the reading of a printed text are not completely identical processes. The author justifies her stance by sustaining that the reading of documents on the Internet, is, on the one hand, based on critical skills and cognitive processes that characterise printed reading (such as automatism in deciphering letters, reading fluency and the involvement of inferences in the process of signification). However, on the other hand, it brings in new complexities to the understanding of the text, higher levels of strategic processing and additional cognitive, metacognitive and emotional competencies. Thus, online reading requires, according to Carioli (2014), that the reader masters the following skills:

- the commitment required in the selection and assessment - of the relevance and reliability - of multiple and dynamic sources,

- the need to adopt a selective and strategic reading that allows avoiding the distractions of the barrages and to restrain the continuous sensorial pressures,

- the need to find the way in a deconstructed environment such as the online one, in which the reader, unlike the author, determines a way through the labyrinth of online texts, in the absence of these typographic references (numerical and structural) that guide the reader of a printed book,

- the increasing importance of being able to logically integrate textual fragments, summarise and ascribe meaning to multiple materials, which are activities that require higher awareness and 
control of the cognitive processes than the reading in a printed format (p. 111).

Currently, a substantial part of the reading in the higher education academic study is carried out in a digital milieu (Lincoln, 2013; Sackstein et al., 2015; Kretzschmar et al., 2013), which has potential to be explored in its enormous wealth (Myrberg \& Wiberg, 2015). This new reality is transforming (or may transform, if explored), or at least influence the structure of a text, its content and the reading process itself (Cordón \& Jarvio, 2015; Mozuraite, 2014; Carioli, 2014; Hermosillo \& González, 2018).

\section{Methods}

The research question that gears this conceptual paper is the following: what is the pedagogical potential of digital reading in scrolling text (without hyperlinks)? To seek to answer this question, a document collection and analysis was carried out on B-on (Online Knowledge Library), which provides unlimited and permanent access, on the part of Portuguese research and higher education institutions, to full texts of scientific journals and other publications (Biblioteca do Conhecimento Online, n.d.).

Next section provides a comparison between printed reading and digital milieu reading through scrolling textbooks and other teaching materials in the specific context of higher education learning. To do so, we will seek to analyse the advantages, differences and limitations, with the purpose of understanding the pedagogical potential of digital reading compared to printed reading that may support the growing use of digital reading.

\section{The Reading on the Scrolling Text Screen}

\subsection{Technological comparison}

In a comparison between the printed format and the digital format (with the use of screens such as the laptop, desktop, iPad and tablet), the digital format offers a significant set of advantages, such as economy, easiness of access, the fact that it is non-physical and, thus, more manageable/transportable, the possibility of taking up less space, the easiness to search/locate, the increasing amount of material available, the non-degradation, the possibility of writing notes, increasing the font size and searching in the text itself, the possible quick and practical updates, and an increasingly friendly use of the device (Myrberg, 2017; Hou, Wu, \& Harrell, 2017). However, there are also hindrances in the digital format that may influence the reading, notably the technical aspects of the device, such as the quality of the screen itself, which may hamper the search and the reading. In addition, this format may affect eye health (Singer \& Alexander, 2017), which, however, seems to be overtaken (Myrberg, 2017).

In the comparison carried out in this paper, some of the more technological factors are highlighted, but which may also have implications for students and teachers in the preferences and even in the level of success of their reading (Kretzschmar et al., 2013).

This comparison does not allow to automatically conclude that one form of reading has advantages over the other in terms of reading processes (focusing on both speed and understanding). There is no unanimous opinion in the literature about this topic, and there is a clear need for further research (Myrberg \& Wiberg, 2015; Singer \& Alexander, 2017).

Dadico (2017) asserts that, in the online world, "the reader's commitment to memorising the text is reduced, whereas his/her concern with information-seeking strategies increases" (p. 731). It may be argued, from this positioning of the author, that digital reading may run the risk of being made in a more superficial and simplistic way.

Gudinavičius (2016), in his study on the reading of books written in a foreign language, argues that, in fact, the reading format exerts influence, and screen reading entails a higher level of attention and concentration than printed reading. From our standpoint, this may have implications on the reading quality, both in terms of speed and understanding.

Conversely to the positioning of the aforementioned authors, who are based on well-known 
studies, Sackstein et al. (2015) sustain, in their research, that reading in a digital format is faster and has a similar level of understanding to printed reading, and the authors even conclude that tablets and e-books are suitable tools for reading in the academic work of learning. Myrberg and Wiberg (2015) have a similar stance and conclude, in their review, that there are no significant differences in understanding a text between both reading formats.

\subsection{Students' preferences}

Besides these more technological aspects, what are the students' preferences and their relationship with the level of reading?

In the specific analysis of university students' reading practices, the research carried out by Gil (2016) reveals that

[...] students read both on screen and paper, and this depends, among other factors, on the purpose of the reading and the extension of the text. On screen, they usually read webpages, blogs and secondary texts, such as abstracts, slides and other students' works, rather than academy's canonical texts: books and scientific articles (p. 80).

Myrberg and Wiberg (2015) and Myrberg (2017) seek to understand why a very large number of students still prefer printed books over e-books. The authors conclude that, very frequently, on the basis of this preference are a priori defined stances, technical reasons (such as the fact that the screen leads to eyestrain), ignorance on the part of the students of how to benefit from the potential of the e-book and the fact that it is not very user-friendly. However, the authors argue that at least the technical aspects can be overcome.

In turn, Singer and Alexander (2017) posit that, although digital texts are more appealing to students, and that, despite "students typically predicted better comprehension when reading digitally" ( $p$. 155), the reading results are similar. The preference is, therefore, not necessarily related to obtaining better results by students.

Kretzschmar et al. (2013) sustain that, if circumstances are adequate, digital media can offer advantages in terms of reading, especially if they positively discriminate senior readers. The authors contend that

Comprehension accuracy did not differ across the three media for either group. We argue that these results can be explained in terms of the better text discriminability (higher contrast) produced by the backlit display of the tablet computer. Contrast sensitivity decreases with age and degraded contrast conditions lead to longer reading times, thus supporting the conclusion that older readers may benefit particularly from the enhanced contrast of the tablet. Our findings thus indicate that people's subjective evaluation of digital reading media must be dissociated from the cognitive and neural effort expended in online information processing while reading from such devices (p. 1).

There may also be differences in the reading speed and understanding, taking into account the features of the population in question, as well as their knowledge and familiarity (Mozuraite, 2014; Myrberg \& Wiberg, 2015; Singer \& Alexander, 2017; Sackstein et al., 2015; Gil, 2016; Harvey \& Walker, 2018). Myrberg and Wiberg (2015) argue that "[...] even those who prefer to read on screens are originally native paper readers, and as long as the existing application interfaces cannot address the shortcomings of screens regarding spatial landmarks, we will keep returning to paper under certain circumstances" (p. 49).

Thus, in addition to attitudes and predispositions on the part of the public (Hou et al., 2017; Myrberg \& Wiberg, 2015), the issue of technical knowledge is also relevant (Golan et al., 2018; Macedo-Rouet, 2003; Myrberg \& Wiberg, 2015). As an example, "technophobia" is regarded as negative anxiety feeling about technology, which leads to a negative expectation on the part of the likely user, and that may act as (yet another) barrier that hinders screen literature (Hou et al., 2017). 


\subsection{Reading results}

This process of transition to the digital format is, thus, not linear in the sense that everyone is moving towards or preferring printed reading over digital reading (Lincoln, 2013). There are differences between people, just as the same person may prefer a certain type of information on the screen but another type of information on paper, with different preferences in terms of format and reading habits (Tanjung et al., 2017). In this regard, Sackstein et al. (2015) maintain that

This does not imply that all students' reading comprehension will be unimpeded by an electronic reading device, and therefore educators must still make an effort to assess whether each individual student comprehends effectively from an electronic medium, as not all students comprehend in the same way (p. 11).

As a consequence, there is the need not to assume that all students are equipped with digital reading kills, and it is necessary to teach many of them how to carry out this kind of reading (Gil, 2016). According to O'Sullivan (2018),

[...] students, in spite of notions of young people's digital immersion, appreciate print for reasons based on its various inherent affordances, including strong pragmatic considerations, but that, also pragmatically, they adapt their reading behavior toward the conveniently accessible digital in order to accommodate the structured environment in which they study [...] In reading for academic purposes, students are responding rationally to the conditions pertaining to access, from the high cost of materials in physical form to the provision of readings online, with an increasing proportion of longer texts in the form of ebooks (p. 366).

Table 1 depicts the results of the reading skills, on the basis of the conclusions of Hermosillo and González's (2018) research.

Table 1. Results of the reading abilities

\begin{tabular}{|c|c|c|}
\hline Skills & Identified as & Results regarding reading in an electronic device \\
\hline Technical & $\begin{array}{l}\text { Mastery of the material support: } \\
\text { Manipulation of the book and its } \\
\text { pages, signalling, functions of } \\
\text { the electronic device. }\end{array}$ & $\begin{array}{l}\text { Are required as prerequisites for reading. Are quickly } \\
\text { attained, with direct support from another experienced } \\
\text { reader. Are developed with direct and repeated } \\
\text { experience, and with indirect support. Participation in } \\
\text { communities is a valuable resource for the full mastery of } \\
\text { these skills. }\end{array}$ \\
\hline Visual & $\begin{array}{l}\text { Motor functions: } \\
\text { Eye control, fixations, fluidity, } \\
\text { speed and rhythm, movement } \\
\text { sequence. }\end{array}$ & $\begin{array}{l}\text { Are favoured by the ability to adapt the device to the } \\
\text { reader's needs. Some readers mention visual difficulty } \\
\text { derived from the lighting features of some screens. }\end{array}$ \\
\hline Strategic & $\begin{array}{l}\text { Actions to achieve the reading } \\
\text { goal: select, locate, focus, } \\
\text { underline, comment, retain, } \\
\text { discriminate. }\end{array}$ & $\begin{array}{l}\text { Are carried out with greater agility. Risk of trivialisation. } \\
\text { Possible resource of interaction with other readers. } \\
\text { Impacts on the de-sacralisation of the book as an object. }\end{array}$ \\
\hline Cognitive & $\begin{array}{l}\text { Understand, interpret, analyse, } \\
\text { synthesise, associate, prioritise, } \\
\text { anticipate, infer, question, } \\
\text { abstract. }\end{array}$ & $\begin{array}{l}\text { There is no distinction in terms of the format, but some of } \\
\text { them are ignited from the interaction with other readers. }\end{array}$ \\
\hline Affective & $\begin{array}{l}\text { Related to the emotions, } \\
\text { motivations and meanings } \\
\text { entailed in the text. }\end{array}$ & $\begin{array}{l}\text { Are ignited, not by the use of the device itself, but by the } \\
\text { interaction with other contents and other readers, which } \\
\text { is facilitated with the electronic device. }\end{array}$ \\
\hline Social & $\begin{array}{l}\text { Abilities to express, discuss, } \\
\text { debate and reframe the } \\
\text { collective reading. }\end{array}$ & $\begin{array}{l}\text { Are developed by interacting with other readers and by } \\
\text { belonging to a community of reference, whether in } \\
\text { person or technologically mediated. }\end{array}$ \\
\hline
\end{tabular}

Source: Hermosillo and González (2018, p. 9). 
Rogers-Estable (2018) carried out a study in a higher education institution, with the goal of obtaining faculty members' perceptions of the advantages and disadvantages of implementing a one-to-one iPad programme. The author concluded that academics do not deem this type of methodology more relevant to their training and the success of its use in the classroom context. The faculty members identified, as main obstacles, issues associated with "better support of technical challenges, more efficient workflows in implementation, and usability and interactive features of the eTexts" (p. 41). However, faculty members acknowledged that the growing use, in graduate education, of electronic textbooks (e-Texts) and online learning digital resources, to the detriment of traditional paper textbooks ( $p$-Texts), also shows the growing need for "training, connectivity and technical support for using eTexts" (p. 42). Based on the results of her study, Rogers-Estable (2018) proposes a set of recommendations that higher education institutions which are considering implementing similar projects on their campus should take into account:

First, faculty perceptions will negatively or positively affect [the] successful implementation of any project. Faculty are busy and care about student learning as a top priority. If they perceive a value to student learning from a new innovation, then they are more likely to support project implementation successfully. If they do not see the value or find the new tool or innovation more difficult to use than its value merits (in their view), implementation will stagnate. [...] It is recommended to first have pilots in advance of full implementation. This will allow the opportunity for a select few innovative faculty [members] to test the new technology, and make recommendations about faculty needs. Next, 3) efficient workflows are required for smooth implementation (p. 52).

It is, therefore, imperative to be well aware, both of the advantages and disadvantages of reading digital or printed texts, and of other elements related to learning, which is an always complex process in any context. Singer and Alexander (2017) warn that the problem of knowing which method is most likely to have a positive influence on students' performance does not have a simple or easy answer. This issue is, according to the authors, still little studied and

[...] there is still much to be learned about the nature of reading and comprehending when the medium is digital or print, not solely in terms of the cognitive processing that transpires, but also with regard to any motivational, sociocultural, or visual-motor factors that are implicated ( $p .167)$.

However, given the increasing presence of virtual ways of accessing knowledge, this issue will necessarily have to be the target of more in-depth studies to assess their positive influence on students' learning processes and, consequently, on their academic development (Singer \& Alexander, 2017).

\section{Conclusion}

Digital reading on a screen is inevitable and is here to stay. The studies carried out so far, together with the fact that we live in an increasingly technological, digital and virtual world, point towards the fact that this type of reading will be increasingly used in higher education learning. It has huge potential benefits, provided that it is well used by both teachers and students, in addition to meeting the growing expectations of most students and many academics.

Nevertheless, this process does not entail a simple transition from printed reading to screen reading (Cline, 2012), or a transposition between students' digital and online experiences and the practice of academic reading. Gil (2016) alerts that

Screen reading requires knowledge and understanding skills that could also be applied to printed sources, but it also requires specific skills in terms of the digital environment. [...] In this regard, although young people are considered to have a good mastery of technology, it should not be assumed that they already master the reading practices that are specific of the academic context ( $p$. 81).

In consequence, reading in general and, specifically, in the digital context, will have to be a 
joint effort that all stakeholders have to foster (Tanjung et al., 2017; Gil, 2016; Cline, 2012), preferably since the first years of the schooling process (Myrberg \& Wiberg, 2015; Mozuraite, 2014). This effort is grounded on the inescapable fact that "children today read in a slightly different way in comparison to adults who were introduced to computers in their adulthood" (Mozuraite, 2014, p. 83).

This reading in a digital format does not, therefore, imply that it is necessarily profitable in terms of learning, and it may, for example, be or not be a motivating factor (Long \& Szabo, 2016; Sackstein et al., 2015). Not all students prefer it, just as the situation under analysis may exert influence on the preference (Myrberg, 2017; Cline, 2012). Myrberg and Wiberg (2015) state that, "as long as we are not all native digital readers, there will be occasions when most of us will be more comfortable reading printed text, for example, when proofreading" (p. 53).

Summing up, this new reality entails special attention from students, but also from teachers, regarding their strategies of teaching and motivation in the promotion of skills and contents, but also in a way that students get to be equipped with the tools and knowledge necessary and sufficient to carry out this reading process (Girón-García, \& Navarro i Ferrando, 2014; Gil, 2016; Knight, 2015; Santos \& Serpa, 2017; Upegui et al., 2013).

The pedagogical intentionality, which runs parallel with the teacher-student relationship (Long \& Szabo, 2016) seems, hence - although in an up-to-date way that allows responding to these new reading features - to remain central, so that, in digital reading, it may be possible not only to browse and see information, but also to read it (Ribeiro, 2009; Dadico, 2017) in its complete meaning and, thus, to learn and understand it.

\section{References}

Biblioteca do Conhecimento Online (n.d.). What is b-on? Available at https://www.b-on.pt/en/what-is-b-on/. Accessed on January 17, 2019.

Carioli, S. (2014). Verso una pedagogia innovativa della lettura: Codici testuali e codici digitali [Towards an innovative reading pedagogy: Textual codes and digital codes]. Studi sulla Formazione, 2, 105-117. doi: 10.13128/Studi_Formaz-16183.

Cassany, D., \& Morales, O. A. (2008). Leer y escribir en la universidad: Hacia la lectura y la escritura crítica de géneros cientificos [Reading and writing in the university: Towards reading and critical writing of scientific genres]. Revista Memoralia, 5, 69-82.

Cline, B. J. (2012). The future of reading/thinking: Epistemological construction in the age of the kindle. Communication $+1,1$, Article 2 .

Cordón, J. A., \& Jarvio, A. O. (2015). ¿Se está transformando la lectura y la escritura en la era digital? [ls reading and writing being transformed in this digital age?]. Revista Interamericana de Bibliotecología, 38(2), 137-145. doi: 10.17533/udea.rib.v38n2a05.

Dadico, L. (2017). Modos de ler livros em meios digitais: Transformações da experiência [Ways of reading books in digital media: Transformations of experience]. Psicologia: Ciência e Profissão, 37(3), 725-737. doi: 10.1590/1982-3703004662016.

Gil, K. S. L. (2016). Práticas de lectura digital de estudantes universitários [Digital reading practices of university students]. Enseñanza \& Teaching, 34(1), 57-92. doi: 10.14201/et20163415792.

Girón-García, C., \& Navarro i Ferrando, I. (2014). Digital literacy and metaphorical models. Multidisciplinary Journal for Education, Social and Technological Sciences, 1(2), 160-180. doi: 10.4995/muse.2014.2991.

Golan, D. D., Barzillai, M., \& Katzir, T. (2018). The effect of presentation mode on children's reading preferences, performance, and self-evaluations. Computers \& Education, 126, 346-358. doi: 10.1016/j.compedu.2018.08.001.

Gudinavičius, A. (2016). Towards understanding the differences between reading on paper and screen: Measuring attention changes in brain activity. Libellarium, IX(1), 175-184. doi: 10.15291/libellarium.v9i1.240.

Gulley, N. (2013). Creative commons: Challenges and solutions for researchers; a publisher's perspective of copyright in an open access environment. Insights, 27(2), 168-173. doi: 10.1629/2048-7754.107.

Harvey, H., \& Walker, R. (2018). Reading comprehension and its relationship with working memory capacity when reading horizontally scrolling text. Quarterly Journal of Experimental Psychology, 71(9), 1887-1897. doi: $10.1080 / 17470218.2017 .1363258$.

Hermosillo, M. M., \& González, J. R. V. (2018). Leer más allá de las líneas. Análisis de los procesos de lectura digital desde la perspectiva de la literacidad [Read beyond the lines. Analysis of digital reading processes from the perspective literacy]. Sinéctica. Revista Electrónica de Educación, 50. Available at https://sinectica.iteso.mx/index.php/SINECTICA/article/view/776/1003. Accessed on March 20, 2019. 
Hou, J., Wu, Y., \& Harrell, E. (2017). Reading on paper and screen among senior adults: Cognitive map and technophobia. Frontiers in Psychology, 8. doi: 10.3389/fpsyg.2017.02225.

Knight, B. A. (2015). Teachers' use of textbooks in the digital age. Cogent Education, 2, 1015812. doi: 10.1080/2331186X.2015.1015812.

Kretzschmar, F., Pleimling, D., Hosemann, J., Füssel, S., Bornkessel-Schlesewsky, I. et al. (2013). Subjective impressions do not mirror online reading effort: Concurrent EEG-Eyetracking evidence from the reading of books and digital media. PLOS ONE 8(2), e56178. doi: 10.1371/journal.pone.0056178.

Lenhard, W., Schroeders, U., \& Lenhard, A. (2017). Equivalence of screen versus print reading comprehension depends on task complexity and proficiency. Discourse Processes, 54(5-6), 427-445. doi: 10.1080/0163853X.2017.1319653.

Levratto, V. (2017). Encuentro entre lectura en papel y lectura digital: Hacia una gramática de lectura en los entornos virtuales [The meeting between paper reading and digital reading: Towards a reading grammar in virtual environments]. Foro de Educación, 15(23), 85-100. doi: 10.14516/fde.555.

Lincoln, T. D. (2013). Reading and e-reading for academic work: Patterns and preferences in theological studies and religion. Theological Librarianship, 6(2), 34-52.

Long, D., \& Szabo, S. (2016). E-readers and the effects on students' reading motivation, attitude and comprehension during guided reading. Cogent Education, 3, 1197818. doi: 10.1080/2331186X.2016.1197818.

Macedo-Rouet, M. (2003). Legibilidade de revistas eletrônicas de divulgação científica [Readability of electronic journals of scientific dissemination]. Ci. Inf., 32(3), 103-112.

Martin-Beltrán, M., Tigert, J. M., Peercy, M. M., \& Silverman, R. D. (2017). Using digital texts vs. paper texts to read together: Insights into engagement and mediation of literacy practices among linguistically diverse students. International Journal of Educational Research, 82, 135-146. doi: 10.1016/j.ijer.2017.01.009.

Mozuraite, V. (2014). Change of the reading paradigm in the age of e-book. Libellarium, VII(1), 83-91.

Myrberg, C. (2017). Why doesn't everyone love reading e-books? Insights, 30(3), 115-125. doi: 10.1629/uksg.386.

Myrberg, C., \& Wiberg, N. (2015). Screen vs. paper: What is the difference for reading and learning? Insights, 28(2), 49-54. doi: 10.1629/uksg.236.

O'Sullivan, J. (2018). Beyond solutions: Students' rationales for print and screen reading in Irish higher education. Telematics and Informatics, 35(2), 358-369. doi: 10.1016/j.tele.2017.12.012.

Phamonvaechavan, P., \& Nitiapinyasagul, R. (2017). A comparison between effect of viewing text on computer screen and iPad on visual symptoms and functions. Siriraj Medical Journal, 69(4), 185-189.

Ribeiro, A. E. (2009). Navegar sem ler, ler sem navegar e outras combinações de habilidades do leitor [Browsing without reading, reading without browsing and other combinations of reader competencies]. Educação em Revista, 25(3), 75-102.

Rogers-Estable, M. D. (2018). Implementation factors and faculty perceptions of electronic textbooks on the iPad. Open Praxis, 10(1), 41-54.

Ruiz, M. E. M, Macías, R. C. F., \& Cano, J. M. M. (2017). El papel de las estrategias y los conocimientos previos al leer en Internet: Revisión y discusión de la literatura relevante al tema [The role of strategies and prior knowledge on reading on the internet: Review and discussion of the relevant literature on the topic]. Avances en Psicología Latinoamericana. 35(1), 131-141. doi: 10.12804/revistas.urosario.edu.co/apl/a.3624.

Sá, M. J., \& Serpa, S. (2018). Transversal competences: Their importance and learning processes by higher education students. Education Sciences, 8(3), 126. doi: 10.3390/educsci8030126.

Sackstein, S., Spark, I., \& Jenkins, A. (2015). Are e-books effective tools for learning? Reading speed and comprehension: iPad®i vs. paper. South African Journal of Education, 35(4), 1-14. doi: $10.15700 /$ saje.v35n4a1202.

Santos, A. I., \& Serpa, S. (2017). The importance of promoting digital literacy in higher education. International Journal of Social Science Studies. 5(6), 90-93. doi: 10.11114/ijsss.v5i6.2330.

Shihab, I. A. (2011). Reading as critical thinking. Asian Social Science, 7(8), 209-218. doi: 10.5539/ass.v7n8p209.

Singer, L. M., \& Alexander, P. A. (2017). Reading across mediums: Effects of reading digital and print texts on comprehension and calibration. The Journal of Experimental Education, 85(1), 155-172. doi: 10.1080/00220973.2016.1143794.

Tanjung, F., Ridwan, R., \& Gultom, U. (2017). Reading habits in digital era: A research on the student's in Borneo University. Language and Language Teaching Journal, 20(2), 147-157. doi: 10.24071/llt.2017.200209.

Upegui, A. A. S., Ceballos, L. M., Rendón, J. C., \& Gil, C. A. (2013). Alfabetización académico-investigativa: Citar, argumentar y leer en la red [Academic-investigative literacy: Quoting, arguing and reading online]. Revista Lasallista de Investigación, 10(2), 151-163. 